\title{
The Changing Corporate Governance Paradigm: Implications for Transition and Developing Countries
}

\author{
By: Erik Berglöf and Ernst-Ludwig von Thadden
}

Working Paper Number 263

June 1999 


\title{
The Changing Corporate Governance Paradigm: Implications for Transition and Developing Countries
}

\author{
Erik Berglöf * \\ and \\ Ernst-Ludwig von Thadden**
}

June 1999

* SITE, Stockholm School of Economics and CEPR.

** DEEP, Université de Lausanne and CEPR

Both authors are grateful to the Center for Advanced Study in the Behavioral Sciences, Stanford, California, for providing such a stimulating environment for writing this paper. We 
also appreciate comments from Masahiko Aoki, Bernie Black, Florencio Lopez-de-Silanes, Joseph Stiglitz, and two anonymous referees. 


\begin{abstract}
The rapidly growing literature studying the relationship between legal origin, investor protection, and finance has stimulated an important debate in academic circles. It has also generated a number of applied research projects and strong policy statements. This paper discusses the implications, in particular for developing and transition countries, from this literature. We conclude that its focus on the plight of small investors is too narrow when applied to these countries. We argue that this group is unlikely to play an important role in most developing and transition countries. External investors may still be crucial, but they are more likely to come in as strategic investors or creditors. The paper also proposes a broader paradigm including other stakeholders and mechanisms of governance in order to better understand the problems facing these countries and generate policy implications that compensate for the weaknesses of capital markets.
\end{abstract}

Key Words: Corporate governance, corporate law, economic transition, economic development

JEL Classification: D23, G32, G38, K22, O17 


\section{Introduction}

Corporate governance has been a dominant policy issue in developed market economies for more than a decade, lately particularly in Continental Europe and Japan. In the transition economies it took some time for corporate governance to climb the ladder of policy priorities, but since the mid- ' 90 s it has been one of the most hotly contested issues. In the wake of the Asian Crisis, corporate governance has also become a catchword in the development debate. Countries and stock exchanges are competing to produce corporate governance guidelines, and OECD is about to publish its own principles.

But how important is corporate governance? For some, it is among the most important policy issues of all, others claim its effects are second-order. These differences in opinion may reflect the fact that people mean different things when they use the concept. Another explanation could be that corporate governance is not always important, but that it matters very much when it matters; it certainly seems to be more important in some phases of a firm's life cycle than in others. Corporate governance is also likely to matter more in certain contexts or certain phases of economic development than in others.

Ultimately, of course, when and how much corporate governance matters is an empirical question. A recent series of articles has begun to address these issues from a comparative empirical perspective, promising more precise definitions of the corporate governance problem and better measurements of its impact on economic growth (LaPorta et al., 1997, 1998, and 1999a; for simplicity we will refer to their three main articles as LLSV where a more precise reference is not absolutely necessary). The authors - Rafael LaPorta, Florencio Lopez-de-Silanes, Andrei Shleifer, and Robert Vishny - raise a range of important questions concerning the interaction between law and finance, and more broadly about the role of institutions in economic development. Their articles have already given rise to a cottage industry of research on the interaction between law and finance. Recent contributions analyze the effects of legal rules protecting investors and the general quality of the legal system on, for example, the development of the financial system (Levine et al., 1998), the impact of macroeconomic shocks (Johnson et al., 1998), the cost of capital (Lombardo and Pagano, 1999), and corporate behavior and industrial growth (LaPorta et al., 1999b; Rajan and Zingales, 1998, Carlin and Mayer, 1998). In many cases the explanatory power of the legal variables is very strong, suggesting that the potential implications for policy are important.

LLSV document statistically and explain theoretically cross-country variations in ownership concentration and financing arrangements. Their main argument is that when the legal framework does not offer sufficient protection for outside investors, entrepreneurs and original owners are forced to maintain large positions themselves to align their incentives with other shareholders (Shleifer and Vishny, 1997). In other words, countries with poor shareholder protection should have more concentrated ownership structures. LLSV find support for this hypothesis, and they argue that differences in investor protection have implications for corporate behavior and economic growth. 
The present article discusses how the findings in this rapidly growing literature should be interpreted. In particular, we would like to understand its implications for transition countries and developing economies. Although the recent contributions have raised a range of interesting questions and expanded the empirical base on which economists form their theories and draw policy implications, we believe that the analysis is incomplete and normative conclusions are often premature. The analysis is incomplete mainly because it focuses on only one group of actors, small outside investors, in the corporate governance problem. The fate of corporations de facto is, and possibly should be, determined by other actors inside and outside the firm as well. The net for empirical investigations must therefore be cast wider. We recognize the ingenuity and importance of this first generation of empirical corporate governance papers, but we emphasize that so far, few general conclusions can be drawn and any recommendation for policy must be based on an analysis of the specific governance problem in the given country.

This recent literature is based on the premise that the main corporate governance problem is self-interested management and weak, dispersed shareholders. The need to raise external finance determines the structure of the firm and the legal framework in which it operates. In this sense the literature follows a long tradition. However, in their quest to understand the interaction between the legal framework and corporate governance, the contributors have shown that the empirical context from which they derived their world view is highly unrepresentative when taken beyond the United States and the United Kingdom. A rapidly increasing body of cross-sectional studies and comparable country studies demonstrate clearly that the widely held firm is a rare phenomenon in most countries (see LLSV (1998b) and Barca and Becht (1999)). Most firms in the world, even listed firms, have a dominant owner. Moreover, this shareholder is very often involved in the management of the firm. Sometimes, but rarely, a bank will play this role, but in most cases a family or the state holds such a dominant stake. This pattern is strong on the European continent, but it is even more pronounced in developing countries. In the economies in transition, ownership structures are still not well established, but widely held firms are extremely rare, even in countries that opted for early mass privatization through vouchers.

The realization that the closely held firm is the dominant form of governance profoundly affects how we conceive of the corporate governance problem and its policy implications. In the debate about ownership and control, the focus shifts from conflicts between management and shareholders to a three-way conflict between large blockholders, managers, and minority investors. Furthermore, the identity of investors comes into play, and it becomes important who monitors them, what their incentives are, and how they are constrained by the legal framework. When the firm is closely held, the emphasis shifts from shareholder-oriented governance institutions such as boards of directors, general shareholders meetings, and takeovers to a broader set of devices for re-designing ownership and control, such as the use of dual class shares, pyramiding of share holdings, cross-ownership, managerial networks, and block trading. And in the analysis of capital market activity, the paradigm of the competitive stock market must be abandoned in favor of models of bilateral negotiations, blockholder conflicts, and market design. In particular, with closely held companies, takeover markets operate very differently. Often, outright hostile offers are literally impossible when one owner 
controls the majority of the shares, and most control transactions take place outside the official exchanges.

There are several ways in which to understand LLSV's implications for policy. A naive and optimistic interpretation of their findings is relatively straightforward: one should strengthen legal rules protecting minority shareholders. This recommendation should be particularly uncontroversial for developing countries and countries in transition where these laws are likely to be weakest. LLSV even provide a list of features of rules that would achieve this result, such as forbidding deviations from one-share-one-vote or allowing proxy voting by mail. Then corporations would be controlled more efficiently, or at least controlling owners would be able to sell off some of their equity, allowing them to better diversify their portfolios and making stock markets more liquid. The remaining problem would primarily be one of implementation and possibly enforcement.

A deeper, but also more pessimistic, interpretation of LLSV's findings is that investor protection is indeed very important, but that the various rules are generated by different legal systems - most important civil law systems and common law systems - that the body of law in a given legal system is highly complementary, and that improvements in investor protection can, therefore, be achieved only by reforming the entire legal system. Such reforms are very complex, however, and may not be an option for many economies in transition; furthermore, in most countries the choice of the legal system either is pre-determined (as in many former colonies) or has already been made, if only half-heartedly and imperfectly. Finally, because the necessary legal reforms cannot be restricted to isolated changes in corporate law, important stakeholders may resist legal reform, making its implementation even more difficult.

To make policy recommendations we, therefore, need to define the corporate governance problem in a particular country with regard to its prevailing institutions. In particular, the predominant corporate governance problem in a transition country is likely to be different from that of a developing economy, which in turn is different from that of a developed market economy. Corporate governance issues also vary substantially across developed market economies (see, for example, Berglöf, 1997; Gugler, 1998; and Barca and Becht, 1999). These differences will affect the implementation of corporate governance recommendations. An interesting case in point is the problem of corporate transparency: according to the market-based view of corporate governance, transparency about ownership and control arrangements is unambiguously a good thing, and several variables in LSSV indicate that many countries outside the U.S. and the U.K. are deficient in this respect. In the light of this type of criticism, the European Commission passed its Transparency Directive in 1993 to increase transparency of corporations in the EU. However, it seems that this directive has achieved little, if anything (ECGN, 1998). Most firms or even countries in Europe seem to have found ways around the restrictions imposed by the Commission. This outcome indicates that piecemeal introduction of legislation advocated by the market-based corporate governance view may not work in economies organized along other lines. 
As we argued above, one reason for this difficulty is that the focus of corporate finance for so many years - the widely held corporation - is a rare phenomenon. But our understanding of the closely held firm, corporate groups, and the markets in which controlling blocks are traded is still limited, and the analysis of the various mechanisms for separating ownership and control has only just begun. In particular, we know little about how to preserve the powerful incentives of owner/managers, especially in family firms, while strengthening the protection of minority shareholders. Furthermore, almost all theory in corporate finance assumes that firms operate under the constraint of a functioning civil and criminal justice system. Such theories must fail in environments where outright and large-scale fraud and theft are standard business practice, such as in Russia or in some African countries.

More generally, however, an important shortcoming of the new corporate governance literature is that it restricts attention to control by the providers of capital, often even further to control by equity holders. In a legalistic sense, this restriction may be justified, because equity holders formally "own" the firm unless it is bankrupt, in which case ownership of the firm or parts of it may switch to other providers of capital. The implicit argument that who owns should control, however, is flawed in many respects. First - and this is, of course, at the heart of the traditional corporate governance literature - there is a big difference between "should" and "does". More generally than the traditional literature, however, this difference relates not only to the conflict between top management and equity. Other groups inside and outside the firm exert significant influence on at least some decisions by the firm. These include the employees as a whole (sometimes formally represented through worker councils or other institutions), higher and middle management, trade unions, firm-specific suppliers or buyers, other large firms which are not linked to the given firm by equity stakes, the public, and the government.

In this paper we, therefore, argue that the market-based corporate governance approach should not only be broadened to include the problem of owner-controlled firms and large blockholders, but should be generalized to a model of multilateral negotiations and influenceseeking among a number of different stakeholders. Such a model in practice must integrate a number of checks and balances between various stakeholders and outside constraints and must take into account how a country's legal and political system affects this balance. In fact, even if there is theoretical reason to believe in the view that ownership with all its costs and benefits belongs to equity, this view is not dominant in most economies outside the U.S. and the U.K. The broader notion of corporate governance then offers some hope for understanding other economies better, in particular those in development or transition, where anonymous stock markets are unlikely to promote the necessary entrepreneurial activity and corporate restructuring. It suggests that other mechanisms, such as product market competition, peer pressure, or labor market activity, may compensate for this weakness, or more realistically, may be more promising targets for legal or political reform than the stock market. Of course, investor protection will still be important, in particular if strategic investors are needed to restructure companies in transition economies, but it becomes one policy goal to be weighed against others. In the long run, protecting small foreign investors may also help attract international portfolio investment, but this source of funds is highly volatile and cannot be the centerpiece of a development program. 
This broadening of the perspective on corporate governance implies that the empirical focus of LLSV on shareholder concentration and corporate law, although operational and statistically useful, is likely to be too narrow. LLSV are silent on the role of suppliers, employees, product markets, or management networks and on those bodies of law that affect their workings and interactions, such as labor laws or competition law. In particular, corporate governance is isolated from product and labor markets. Another interesting aspect that is largely overlooked is the interaction between corporate governance arrangements and the political system. We argue that "crony capitalism" may indeed be a much more important problem in most developing countries than the protection of minority shareholders, mainly because dominant family owners of business groups are influential politically. As this influence has often succeeded in influencing legislation and regulation in the past, we fear that policy recommendations to simply change these rules are insufficient.

The outline of the paper is as follows. Section 2 briefly goes through the main findings in the literature with an emphasis on the empirical contributions. The following section (Section 3) discusses how these findings should be interpreted in the context of a broader view of corporate governance and the firms. Section 4 reviews some of the findings on the relationship between corporate governance and economic growth. Sections 5 and 6 apply the basic framework to the corporate governance problem facing developing economies and transition countries, respectively. The last two sections (Sections 7 and 8) draw some implications for policy.

\section{Law and Finance}

The articles of LLSV have an ambitious agenda. They want to establish systematic, even causal, links between the legal framework and financing patterns, and ultimately corporate performance and economic growth. The causal chain could be described by Figure 1. Legal origins are classified as Anglo-Saxon, French, German, and Scandinavian, or simply common law (Anglo-Saxon) and civil law (the three others), and they are viewed as exogenous, that is, handed down through history or imposed from the outside. The legal origin shapes the corporate law, in particular the extent to which it protects external investors. Corporate law influences the choice of financial arrangements in individual firms. The implicit claim is that these financial arrangements in conjunction with the legal framework then affects corporate behavior and performance. This section summarizes the main findings and provides a first critique.

\section{FIGURE 1}

$\begin{array}{lllll}\text { Legal } & \text { Corporate } & \text { Financial } & \text { Corporate } & \text { Economic } \\ \text { Origin } & \text { Law } & \text { Arrangements } & \text { Behavior } & \text { Growth }\end{array}$


The presumption by LLSV is that the different sets of variables can be quantified and observed. In particular, the authors assume that corporate law can be meaningfully reduced to a set of measures, often binomial, which capture the degree of investor protection. LLSV offer eight indicators for shareholder protection and six for creditor protection (see Table 1). These measures are supplemented by more or less generally accepted indices of "rule of law" and quality of accounting standards. The authors establish a strong correlation between legal origin, investor protection, and ownership concentration; when they control for investor protection the significance of legal origin disappears, suggesting that legal origin primarily affects finance through investor protection. They also identify some potentially interesting differences between countries at different levels of development. We will return to these differences later.

\section{TABLE 1: INDICATORS OF INVESTOR PROTECTION}

\section{Shareholder protection}

One share - one vote

Proxy by mail allowed

Shares not blocked before meeting

Cumulative voting/proportional rep.

Oppressed minority

Preemptive rights to new issues

$\%$ of share capital to call an ESM

Mandatory dividend

\section{Creditor Protection}

No automatic stay

Secured creditors paid first

Restrictions for going into reorganisation

Management leaves in reorganisation

Legal reserve requirements

Many lawyers have been critical of the classification of countries by legal origins. They find the distinction between common law and civil law particularly superficial. Common law countries have a considerable degree of codification (for example, many of the rules protecting investors under US law are described in the Uniform Commercial Code and creditor protection is in part defined by the Bankruptcy Code of 1978) and civil law countries have developed powerful bodies of case law. In classifying individual countries, LLSV draw on an admittedly controversial standard textbook in comparative law. The classifications of some countries have been challenged, and others have emphasized the differences within the two groups. But even if the authors' use of labels can be legitimately criticized, the strong correlation remains to be explained. It is hard to see that a few reclassifications would radically change the results.

\section{TABLE 2 INDICATORS OF ENFORCEMENT}

Efficiency of judicial system

Rule of law

Corruption

Risk of expropriation

Risk of contract repudiation 
Rating on accounting standards

Another criticism put forth by representatives of the law profession is that the authors are using biased or misleading measures of the quality of corporate law. Behind the measures of investor protection obviously lie qualitative judgments, but in principle it could eventually be possible to agree on the appropriate characterizations. Even if this quantification were accurate, the danger is, of course, that the quantifiable aspects of the law provide a biased picture or that the conceptual framework used for identifying these measures is flawed. Different legal systems find different ways to compensate for their weaknesses. For example, mandatory dividends are not common in Anglo-Saxon countries, but are a feature of many civil law countries, particularly in the third world, indicating that this measure is intended to compensate for poor protection in other respects. The problem of investor protection could also have more dimensions, and the measures may miss one or more of these. For example, junior and senior creditors may have very different interests; laws that protect one group may harm the other. We will return to this latter problem in our discussion of the theoretical foundation for the approach. Again, even if there are these biases, critics must explain the systematic and strong correlation the authors establish.

Another potentially more serious criticism concerns the causality claim: that corporate law drives corporate finance and not the other way around. It is not difficult to come up with examples showing how corporate law in writing and enforcement has been shaped by existing financial structures. Countries with a tradition of strong bank involvement in corporate control have often found effective ways of accommodating this tradition in legal practice (see, e.g., Japan and Sweden). Similarly, in countries where closely held firms predominate, legislators and regulators have often found it unnecessary specifically to regulate the composition of boards of directors. When there is a clearly identifiable controlling owner, he or she is believed to be better suited and to have the right incentives to make optimal decisions. The authors' response to this criticism is that legal origin, if not corporate law as such, is highly exogenous, indeed often imposed by colonial powers. The fact that countries with one legal origin score significantly worse along the measures used in the articles must still be explained.

The causality issue brings up another possible problem with the interpretation of the results. It could be that the correlation between legal origin and financing arrangements merely reflects the influence of a third exogenous variable, such as the role of the state or the nature of the political system. In other words, the poor performance of countries with French legal origin would reflect the strong French tradition of state intervention or the French political system; what was imposed on Latin American countries was not just the legal tradition but the entire system of government. Another similar underlying variable could be fundamental differences in the relationships between stakeholders in society (Roe, 1999). But it is not clear how such differences are transferred across countries and cultures. All these explanations challenge the interpretation of the results, but they still leave a strong correlation between origin, however broadly defined, and investor protection and financing arrangements. 
LaPorta et al. (1999a) follow up their previous two articles by describing in greater detail the differences across countries in ownership and control in listed firms in a smaller number of countries where data were available. The authors go to considerable trouble to document both direct and indirect control, that is, when a firm is controlled by another firm, which in turn may be controlled by a third entity, and so on. This requires information on the use of various control mechanisms such as dual class shares, pyramiding, and cross-ownership. The authors show that with the exception of the United States and the United Kingdom, the overwhelming majority of listed corporations have a controlling owner who in many cases is actively involved in management. As expected, countries with a common law origin have more widely held firms.

These findings are consistent with and highly complementary to those found in parallel work within the European Corporate Governance Network (summarized in Barca and Becht (1999) and Gugler (1998)). This network strives to establish data comparable across countries, at least for Europe. The contributors have the advantage of access to better quality data than LLSV but for a smaller number of countries. The data allow a more detailed description and analysis of the corporate governance problem in individual countries. This analysis shows some shortcomings in the quality and comparability of the data used by LLSV. The picture that emerges is nevertheless similar, with a strong concentration of ownership and extensive use of various mechanisms for separating ownership and control. Judging from the ECGN studies, banks are more, and the state less, important in corporate governance in Europe than in the world as a whole. The country studies in Barca and Becht (1999) also suggest that LLSV underestimate bank control by missing channels for influence other than direct ownership. In particular, banks in some countries have managed to circumvent formal restrictions on ownership by establishing independent investment companies (Sweden) and informal constraints by using proxy votes (Germany). In addition, the most important source of influence of banks typically comes from their role as concentrated creditors.

Nevertheless, the qualitative and quantitative assessments by Barca and Becht (1999) and Gugler (1999) raise some fundamental questions about the interpretation of the LLSV findings. There are undoubtedly examples of situations where better investor protection seems highly desirable; stories of controlling owners exploiting minority shareholders abound in some countries (Italy is the favorite example in the literature (Zingales, 1995)). But blockholders on the whole appear to be important monitors of management and often actively participate in management themselves (these studies suffer from an obvious problem of endogeneity, i.e., does ownership determine performance or vice versa ?). The jury is out on whether concentration of ownership is good or bad for performance; in some countries, like Austria, Holland, and Spain, companies with concentrated ownership do worse than those with dispersed share holdings, whereas in others the reverse seems to be true (Gugler, 1999). Roe (1999) raises the legitimate point that, if there are any benefits to large blockholders, better legal protection should, if anything, lead to more large blocks being formed, not less.

It is not difficult to find examples of legislation that seem unfair to holders of minority blocks, and the ECGN studies point many of them out, but the basic legal framework is seldom challenged - at least not from within the countries. Is it really probable that these countries 
have lived with the gross inefficiencies suggested by LLSV for decades or even centuries without realizing their fundamental weaknesses? In particular, why have controlling owner/managers been willing to absorb year after year the large costs associated with these inefficiencies without pushing for legal reform? Are these laws protecting minorities really as hard to change as LLSV seem to suggest? After all, any policymaker could walk down the list in Table 1 and propose reforms that supposedly would improve the protection of investors.

Implicit in the LLSV articles is a political economy story where managers and large blockholders effectively block legal reform. In some cases such interpretations seem highly plausible. For example, dual class shares are a crucial ingredient in the exercise of control in many countries (such as Sweden), and preventing deviations from one-share-one-vote would seriously undermine the influence of existing holders of high-voting stock and result in substantial redistribution of wealth (voting shares typically trade at a substantial premium). It is understandable that reforms meet with strong resistance when applied ex post, but ex ante legislation could also have important redistributive effects (see Zingales (1999) for an argument explaining why inequality may feed resistance to stronger investor protection).

The political economy story may explain why inefficient laws remain in place for long periods of time, but the many remaining puzzles suggest that we need to understand the conceptual framework underlying the LLSV studies better before interpreting the observations and drawing policy conclusions.

\section{Corporate Governance and the Firm}

Corporate governance can be defined as the set of mechanisms that translate signals from product markets and input markets into firm behavior. This definition focuses on two elements: the signals generated outside the firm and the control structures inside the firm to execute decisions based on these signals. The definition is deliberately broader than the more traditional ones which focus on the conflict between outside investors and top management (e.g., those of Shleifer and Vishny (1997) or Tirole (1998)), but we think that it is important to recognize at the outset that control over a firm's course involves more than these two groups of actors. Despite its theoretical flavor, this way of looking at corporate governance has important practical implications. It opens up the firm, and its management, to pressures other than that from shareholders. It also emphasizes the need to look at the issue of corporate governance in a wider context of product market competition and corporate links. The definition further suggests that the various forces may be substitutes as well as complements in pushing the firm towards efficiency.

In this section, we place the LLSV view of corporate governance in the broader context of the definition above and provide some thoughts relating it to the modern theory of the firm.

Samuelson (1957) once remarked that in a competitive economy it would not matter whether capital hires labor or labor hires capital. Indeed, if inputs are homogeneous and the only signals coming from markets are competitive prices that leave zero quasi-rents to producers, 
then the only function of corporate ownership is to determine a profit-maximizing production plan and distribute firm revenues according to marginal productivity. In reality, the signals from factor and product markets are richer and more ambivalent than that, the operation of firms generates substantial quasi-rents at least in the short run, and labor input in particular is heterogeneous and difficult to control. Hence ownership does matter.

But even if we first limit attention to the ownership arrangement most commonly encountered in most economies, ownership by capitalists, the analysis of corporate governance is not as straightforward as often claimed. There are two extreme forms of capitalist ownership: the widely held firm and the firm fully controlled by a family without outside ownership. In between there is a continuum of firms with more or less concentrated ownership. The corporate governance problem of the widely held firm has been studied extensively both in theory and practice. Mark Roe (1994) has characterized it as "Strong Managers, Weak Owners" in the US case. This type of firm relies on anonymous finance using primarily arm'slength contracts and third party intervention through the market for corporate control.

The family firm has a different corporate governance problem. Although there may be conflicts between owners and hired managers, these problems are probably of minor importance, as owners are generally believed to be well equipped to control the operations of their firm. The corporate governance problem in the family-held firm arises precisely because there is no outside interest in the firm. On the operational level, the problem is that ownermanagers sometimes fail to recognize business opportunities or pitfalls, in particular in times of change, where outsiders would see them and intervene; the fall of well-known firms such as Wang in the US or Grundig in Germany can be attributed to this type of governance failure. On a different level, corporate governance becomes an issue when there is a succession problem or when the firm decides to raise funds outside the family. In these important but rare situations, the lack of links to the capital market may significantly reduce the value of the firm if outsiders are reluctant to buy assets of which they know little and over which they have little control. The corporate governance problem in the pure family firm can therefore be characterized as "Strong Managers, No Outsiders".

The corporate governance problem in the closely held firm is again rather different. The predominant conflict is that between the controlling owner and minority shareholders. The financing pattern is different in the sense that it mixes arm's-length finance provided by minority investors with control-oriented finance, that is, finance by an outside investor who takes a controlling stake to affect investment decisions directly. Given the size difference of their stakes, small shareholders will then usually find it difficult to challenge large shareholders directly. Moreover, when ownership of financial instruments is concentrated, there are fewer traders in the markets for these instruments making them less liquid, which in turn reduces the value of the "exit" option of small shareholders (Bolton and von Thadden, 1998). To paraphrase the corporate governance problem in the closely held firm, it is one of "Strong Blockholders, Weak Minorities" (a term originally coined by Patrick Bolton).

So far we have discussed the relationship between the firm and its shareholders, and between controlling and non-controlling shareholders. It is worth noting, however, that shareholders 
are only one class of investors. Creditors obviously also contribute funds to the firm, but less appreciated is the fact that suppliers, and sometimes even employees (as currently in Russia), also provide external finance. The state, too, often offers outside funding, either voluntarily, by default (unpaid taxes), or through subsidies after stakeholder pressure.

The objectives of the law become more complex in the case of creditor protection than for shareholder protection. There are at least four potential inefficiencies that the law should ideally address. Debtor-creditor law may be excessively hard, or on the contrary too soft, on management or controlling owners, but the law can also favor inefficient liquidation (when continuation would be optimal) or inefficient continuation (when liquidation is the optimal decision) (Berglöf, Roland, and von Thadden, 1999). In addition, there will typically be conflicts between creditors in case of bankruptcy, depending on the types of their loans and their relationship with the firm, but conflicts may exist much earlier, if different creditors have different lending experiences and intervention capacities. Hence creditors can and will seek to influence a firm in distress in various ways and with various objectives, which cannot be characterized along a single dimension. The simple goal of maximizing creditor protection does not provide much guidance for the design of corporate law.

The discussion so far has focused on external finance, but internal finance is the most important source in most developed countries and is particularly important in countries with widely held firms (Mayer, 1990). The distinction between external and internal finance may no longer be straightforward in the closely held firm. The owner's own contribution to the firm is typically viewed as internal, even if the firm and its owner are legally separated through limited liability. But when the owner/manager turns to distant family members or friends and acquaintances, at what point does internal finance turn into external finance? And what about the group bank in the financial keiretsu in Japan or bank-led corporate groups elsewhere, should the finance it provides be regarded as internal or external?

The consideration of internal finance provides a richer perspective on corporate governance than the traditional shareholder perspective and forces us to come back to Samuelson's (1957) question: who owns the firm and who should own it? Internal funds are the engine of most firms' operations. They crucially influence a firm's ability to compete, invest, and grow, and at the same time they determine the rents and quasi-rents enjoyed by management, lower level employees, and other stakeholders. According to the LLSV model of external investor protection, the main focus of corporate governance legislation should be to help small investors get as much control over these funds as possible. But shouldn't the law also protect management and owner/managers?

Clearly, if the primary objective of policy is the protection of corporate insiders, as it has been until recently in several developing countries, the answer to this question is trivially affirmative. But even if the law has subtler objectives, such as efficiency, the answer is not necessarily negative, because the protection of external investors comes at the expense of managerial incentives and discretion. As, for example, Burkart, Gromb, and Panunzi (1997) argue, when managers are tightly controlled, their willingness to exert effort and take initiative may be weaker, because controlling outsiders cannot commit to respect managerial quasi-rents 
generated through managerial initiative. In the closely held firm this tradeoff also applies to the owner/manager or large blockholder. Restrictions on their discretion are costly efficiency, and maximum protection of minority investors is most likely to be less than optimal.

Building on the literature on ownership and control developed by Grossman, Hart, and Moore (1986, 1990), one can push this argument even further. If the presumption of the LLSV model of corporate governance is true and top management is indeed the de facto residual claimant to corporate profits - through private benefits deriving from power, the choice of pet investment or public relations projects, or outright diversion of funds - then it may well be efficient if management also has some of the residual control rights formally associated with ownership (Hellwig, 1998). The point here is not to advocate the formal transformation of capitalist companies into labor-managed companies in the sense of Samuelson (1957), but the mere observation that modern capitalist corporations resemble labor-managed firms in this one important dimension and that this may be efficient. In this sense, legislation designed to rein in managerial power may have unwanted efficiency consequences.

Other arguments are based on similar general considerations and make the same point: that outside intervention in management may be reduce efficiency. For example, if internal finance is such an important source of capital, it has been argued that management (possibly as a representative of other stakeholders) should in fact have a role in preventing certain outside investors from grabbing internal funds. According to this quite popular view, outside investors do not necessarily take into account the long-term interest of the firm and financial markets are excessively oriented toward the short term. Theoretically, this argument can be shown to be sound if there are asymmetries of information in the capital market (Stein, 1988, von Thadden, 1995), but the empirical evidence concerning short-sightedness in US firms is mixed.

It is only logical to extend the discussion of managerial incentives to the broader group of all stakeholders. The main argument here (Shleifer and Summers, 1988) builds on the insight that many stakeholders of a firm, in particular employees, customers and suppliers, make firmspecific investments, and that these investments are only practical if they are protected by implicit contracts not to be expropriated ex post. However, if the firm is owned by anonymous shareholders who can sell their stakes on the stock market, shareholders cannot credibly commit not to breach these contracts, because once the firm-specific investment has been made and an outsider proposes a high takeover price, it is optimal for shareholders to sell out. According to this reasoning, stakeholders will not invest sufficiently if they are not given some protection against breaches of contract.

It is clear that the stakeholder perspective, in particular when taken to extremes, has its dangers. Deviations from "shareholder value", however defined, easily allow management to hide behind diffuse objectives and opens up possibilities for individual stakeholder groups to capture excessive rents (for a forceful critique along these lines, see Jensen (1993), a more balanced skepticism is expressed by Tirole (1998)). Yet our point is not that shareholders should be disenfranchised to the benefit of one specific other stakeholder group. The theory we have discussed rather suggests that many different stakeholder groups should play their 
part in the corporate governance process, and that what counts and what is delicate is the balance among them. This balance will typically depend on the broader legal and political environment in which the firms in a given economy operate, and not only, as LLSV suggest, on the design of corporate law. The overall nexus of laws affecting firms in a country will, therefore, matter for the analysis of corporate governance. We view it, for example, as no coincidence that Germany's (in)famously weak shareholder protection laws go hand in hand with relatively strict competition policies, far-reaching labor participation laws, two-tier boards favoring extensive managerial networks, and tax laws favoring corporate crossownership.

Whether or not a good normative argument can be made for a stakeholder perspective, it is a fact that in many, if not most, countries stakeholders do share in rents and take part in the decision-making process. This pattern is particularly striking in many transition countries, often as the outcome of the privatization process, but it is also a feature of most continental European countries. In fact, employee participation is very strong in the firms considered by many to be the most advanced corporate arrangement in the capitalist world, the firms with venture capital finance (for analyses of these arrangements in a corporate governance perspective, see Aoki (1998) and Rajan and Zingales (1998)). The broader concept of corporate governance we have proposed here, therefore, not only has theoretical appeal, but is empirically relevant for comparative institutional analysis.

\section{Corporate Governance and Economic Growth}

LLSV implicitly claim that the legal system and the investor protection it provides to external investors strongly influence the behavior of firms and ultimately corporate performance and economic growth. Figure 2 attempts to make explicit an enlarged causal model allowing for exogenous factors other than legal origin and a two-way causal relationship between the legal and financial systems. It also incorporates the influence from input and product markets as suggested by our definition of corporate governance. As yet, little work has empirically tested the claim of LLSV directly, but a number of contributions have studied individual links in the figure. This section discusses some of these empirical studies in the context of a broader model relating corporate governance to economic growth.

\section{FIGURE 2: THE ENLARGED CONCEPTUAL MODEL (see Appendix)}

The discussion in the previous section focused on the balance between different classes of investor and management, but our definition of corporate governance suggests that there are many channels through which signals from input and product markets affect investment decisions. Obviously, the intensity of these signals themselves should be important. For instance, the more competitive are product markets and the stronger the bargaining power of suppliers, the more likely they are to influence the firm's behavior. If management or the controlling owner for some reason is shielded from these pressures, the strength of the signals may not matter. Corporate governance, market competition and pressures from suppliers may be both complements and substitutes. The legal framework may thus have a double role, in 
reinforcing the signals as such and in improving the mechanism whereby they are channeled into investment decisions. In evaluating the impact of legal mechanisms and drawing policy implications, one should take both functions into account.

Whether competition in product markets and corporate governance are substitutes or complements is ultimately an empirical issue. Some recent research has investigated this question. Nickell (1996) and Nickell et al. (1997) study the relative importance of shareholder pressure (the existence of a leading shareholder), debt pressure (measured as leverage), and intensity of competition and whether these forces substitute for or reinforce each other in a sample of British firms. They find some support for the substitution hypothesis. A study of Russian firms finds little, or even negative, impact of competition on restructuring (Earle and Estrin, 1998). Unfortunately, the authors did not have access to data on corporate governance, but the general impression from this study is that this mechanism was very weak at the time. Brown and Brown (1998) suggest that when the regional fragmentation of markets is taken into account, the effect of competition should be stronger. One interpretation of the Russian experience is that competition requires at least a minimum of corporate governance to have an impact on firm behavior. Below such a minimum, the question of whether product markets and corporate governance are substitutes or complements may not be crucial for policy considerations, as long as they both have a positive impact; competition policy becomes even more important if corporate governance is weak.

Another literature has studied the impact of the financial system on economic growth. In one of the articles King and Levine (1993) show that measures of various aspects of the financial system are economically the most significant among a large number of variables related to growth. More specifically, the authors use the share of private institutions in financial intermediation and the size of the banking sector. Later contributions have refined these measures and attempted to control better for reverse causality (Levine et al., 1998). If anything, the strength of the impact of financial variables increases when scrutinized more closely. Levine et al. (1998) also attempt to link their earlier findings to those of LLSV. They suggest that the degree of investor, more specifically creditor, protection explains the development of the financial sector. Indeed, the measures used by LLSV come out strongly significant.

Another set of contributions has focused on the impact of the legal and financial system on corporate behavior rather than performance. Rajan and Zingales (1998) show that under certain assumptions industries dependent on external finance are more developed in countries with better protection of external investors. Rajan, Servaes and Zingales (1998) present evidence that corporate governance affects the degree of diversification of firms. LaPorta et al. (1999b) show that firms in common law system pay more dividends than in their counterparts in civil law countries.

All these findings suggest that investor protection strongly influences firm behavior and probably economic performance and growth. Nevertheless, any policy recommendations must be country-specific, based on the analysis of the dominant ownership and control structures 
and the larger economic system in which they operate. In the following two sections we discuss some preliminary implications for developing economies and transition countries.

\section{Implications for developing countries}

Developing countries probably are an even more heterogeneous group than developed market economies in their basic legal frameworks, corporate ownership, and structure of the financial system. This fact suggests that few general implications can be drawn for these countries, but there are other important considerations when one takes the insights from the literature inspired by LLSV to the developing world. This section discusses some of these considerations.

LLSV are not focusing on the development problem, but they provide data for 22 countries (excluding the Asian NICs), and they do control for GDP per capita in their regressions. There are some interesting observations in these data. As expected, there is a development effect in that several variables, such as rule of law and quality of accounting standards, are positively correlated with GDP per capita. But investor protection does not seem to improve with level of development. In fact, creditor protection is strongest in the least developed countries. LLSV interpret the latter observation as a reflection of the reliance on collateral in these economies. But with respect to these indicators the crucial issue is, of course, whether the text of the law really matters when law enforcement is poor.

In general, there are relatively few listed firms in most developing countries, and in these firms ownership and control is strongly concentrated (LaPorta et al., 1999a; for Asia see also Claessen et al., 1998). The variation across countries is substantial, but with few exceptions firms have a controlling owner, family-controlled firms are important, and many large firms are members of business groups. Business groups are a notable feature of many developing economies (see Granovetter, 1994, Khanna and Palepu, 1997, or Khanna and Rivkin, 1999, for overviews and examples). They are organized through extensive cross-ownership, are often dominated by a controlling family, and often have good contacts in the government (see, for example, Bhagwati (1993) for the case of India, and Fisman (1998) for Indonesia).

The relevance of shareholder protection laws for an assessment of the workings of capital markets in such economies is problematic, because the group-based corporate structure in developing economies is usually seen as just the response to missing capital market institutions. In fact, the most comprehensive empirical study of business groups in emerging economies we know of, by Khanna and Rivkin (1999), finds that in three out of the seven countries with large numbers of business groups (India, Indonesia Taiwan), group membership has a statistically significant positive impact on firm profitability, whereas the impact is indistinguishable from zero in the four other countries (Brazil, Chile, South Korea, Thailand). Hence business groups, with all their opacity, lack of outside accountability, insider dominance, and so on, at least do not seem to harm their own shareholders, given the environment they operate in. More generally, we believe that the corporate governance problem in our broader perspective is an equilibrium problem: the absence of organized markets and small investors gives rise to substitute constructs such as business groups, but the 
existence of these substitutes prevents capital markets and market-based corporate shareholdings from emerging. In such a situation, the modification of corporate law according to the guidelines by LLSV is likely to have little effect and may even be counterproductive.

The consideration of business groups also sheds light on another important aspect of the LLSV literature. The presumption in this literature is that external finance really constrains the growth of firms. In most developed market economies this is probably true for at least some important industries; internal finance is more important and new issues of equity and debt are relatively rare events in firms, but bank debt is frequently used. In developing countries the actual or potential role of external finance is not as clear. Finance, internal or external, will only help when firms have access to profitable projects with low enough risk. But the risk premium is high in many developing countries (weaknesses in investor protection, the rule of law, enforcement and transparency are, of course, part of this premium). Even if such projects are available, firms will most likely draw on internally generated funds before pursuing external sources. Here, business groups play an important role: by channeling resources between the different firms in the group, they relax the liquidity constraint at the firm level. This mechanism is enhanced if the group contains a bank, as is often the case. Again, a legal reform may be harmful in this situation, if it disrupts these channels without establishing new reliable ones (which is quite likely to be the case at least in the short run - see, for example, Blanchard and Kremer (1997) for the case of transition economies).

One feature that stands out in most studies of ownership and corporate control in developing countries is the close ties between business interests and government, often called crony capitalism - as Bhagwati (1993) has put it nicely for the case of India, the economy is enmeshed in a « kafkaesque maze of controls ». This is not a corporate governance problem in the traditional strict sense, but it affects corporate governance in our wider notion, because large family owners often use their influence to limit competition, obtain favorable finance from the government and in other ways alter the game in their favor. Soft budget constraints are common in these arrangements. Crony capitalism can be a strong deterrent to outside investors, in particular when a country is exposed to negative macroeconomic shocks.

Some of LLSV's indicators concerning the « rule of law » capture elements of this political dimension, but we would argue that this side needs to be developed further. For example, Johnson et al. (1998) demonstrate that the measures used by LLSV explain a significant part of the variation across countries in how much they were affected by the Asian crisis. An interesting question worth exploring is why the similar ownership structures that lead to crony capitalism in developing economies do not lead to the same results in Continental Europe. The answer to this question should be closely related to the issues addressed by LLSV. The strength and quality of government is likely to be part of this answer, but features such as competition law and tax law will certainly also play a role. Crony capitalism requires remedies other than investor protection, but it may be that corporate law can help to dismantle some of these unhealthy structures by offering opportunities for a broadening or phasing out of current ownership. 


\section{Transition Economies}

The research program of LLSV was largely triggered by the transition experience; several of the authors have been deeply involved in Russian institutional reform. Yet there are no transition economies in their data set. Although this omission is understandable given the state of the data for these countries, it is nevertheless unfortunate. We argue that the lessons from this body of work are important for transition economies, but that it is dangerous to take them at face value. This section discusses some of these implications, focusing on Central and Eastern Europe and the former Soviet Union.

The transition countries, too, vary considerably in history and current institutional setup, but they do share certain important features. They all have a large sector of former state-owned enterprises that need to be restructured and in many cases phased out. These countries also need new enterprises to emerge in underdeveloped parts of the economy, in particular in the service sector. These two sectors of the economy pose different governance problems. In addition, the transition economies inherited a dysfunctional legal system, and in many cases they had to construct basic institutions from scratch.

The new enterprises have very much the same problem, or lack of problem, as those of developing countries. They are in an early part of the firm life cycle, unlikely to face the problem of intergenerational transfers anytime soon; liquid markets are therefore less important. It is not even clear that they are financially constrained. The problem of the emerging private sector is rather the simultaneous lack of market signals and managerial accountability in much of the former state-owned sector. These enterprises often require strong outside investors to execute painful restructuring, but the dominant pattern in Central and Eastern Europe and the former Soviet Union is insider control. In the absence of wellfunctioning laws, managers with or without shares can effectively expropriate minority investors (who often entered more or less by default through mass privatization or insider privatization schemes). In this situation the protection of external investors is of crucial importance; outsiders must have a possibility to not only accumulate stakes but also exercise control.

Whereas better investor protection as advocated by LLSV is likely to be very important in many transition countries, in particular in the former Soviet Union, the formal legal text is likely to matter much less than in developed market economies. The Russian corporate law provides an interesting example. The original document was prepared under the influence of Western advisors close to LLSV and was strongly inspired by Anglo-Saxon thinking. The approach taken in the law is also very similar to LLSV - in fact, the legal text is close to perfect according to their criteria as listed in Table 1 (Linnarud, 1998). The drafters of the law clearly recognized the limited capacity of the Russian legal system and the need for flexibility. Thus they focused on self-enforcing legal rules and left large holes in the legal text to be filled by case law (see Black and Kraakman, 1996, and Hay and Shleifer, 1998).

The problem is that the cumbersome procedures and weak enforcement powers of the courts deter investors from bringing suits (Russia ranks fourth from the bottom in the world in terms 
of enforcement). The lack of cases means that the large holes in the legal text remain, and investor uncertainty is large. Furthermore, a potentially harmful conflict between the AngloSaxon case law doctrine and the Russian legal tradition has manifested itself during the last few years. Russian courts typically have very high evidentiary standards, relying on documentary evidence, and usually do not consider circumstantial evidence adequate, as is the case, for example, in the US. For this reason, many cases that would be decided in the US are dismissed, a tendency that reinforces the other obstacles to building up a sufficient body of case law. And finally, many lower level courts in Russia are simply corrupt, and therefore case law based on their rulings is often worthless.

Poor investor protection and concentration of ownership also undermine the liquidity of equity markets. The designers of privatization programs in many countries appear to have underestimated this problem. The emphasis was on speed and equity, appropriate corporate governance structures would emerge in due course. But when markets for corporate control are illiquid, initial ownership and control structures become very sticky, something that seems to be at the core of the governance problem in many transition economies. The overwhelming finding from transition economies, at least in Central and Eastern Europe, is that outside, preferably foreign, investors are crucial in bringing about active and deep restructuring (for an early survey, see EBRD Transition Report 1996).

Another important feature of the economic environment in many transition economies, in particular in the former Soviet Union, is the persistence and even worsening of the problem of soft budget constraints (Berglöf and Roland, 1998; and Schaffer, 1998). The lack of financial discipline often stems from the size or number of formerly state-owned enterprises forcing the government to give in to pressures to refinance the loss-making entities. Another source of soft budget constraints in enterprises is weakness in the banking sector. The softness of budget constraints weakens the need to seek outside finance and thus the pressure to restructure; inefficient governance structures are sustained. For corporate governance to have an effect on investment decisions, budget constraints must be hardened.

The predominant corporate governance problem of the large firms in transition economies can thus be summarized as "Omnipotent Managers, Little Resistance". Improved investor protection can help to attract outside capital and force restructuring, but the overriding issue in most countries seems to be law enforcement and government commitment towards the economic reform process (see Dewatripont and Roland, 1997). To be effective, measures to strengthen investor protection must be combined with efforts in other areas, such as to harden budget constraints, to eliminate government corruption, and to re-consider the workings of the court system.

In fact, the Russian example suggests that such measures may not even be sufficient, if the goal of influencing the governance of private firms has lost its base. In the Russian case, there is substantial evidence that many large privatized firms are being run by veritable kleptocrats who are not even interested in managing these firms on a for profit basis. Their real goal, and their comparative advantage, is to plunder the firms' assets and to transfer the loot abroad, if necessary by brute force against opposition (see Black, Kraakman, and Tarassova, 1999, for a 
well-informed and vivid description). In this situation, the normal paradigma of corporate governance - fine-tune the checks and balances on individual self-interest and opportunism changes its meaning so completely that corporate finance theory no longer applies. In particular, advice to protect minority investors (if not interpreted as physical protection) or increase corporate transparency seems to be largely irrelevant, as long as the society's basic rules of economic and political interaction are Leviathanian. It is hard to imagine any checks of kleptocratic insiders if the whole political system has proved unable or unwilling to confront them, but substituting the corporate governance problem of the private firm with that of the government-owned firm through re-nationalization certainly has much appeal in this case.

\section{General Implications}

LLSV have highlighted a number of issues of crucial importance for understanding the relationships between the laws, financing arrangements and economic growth. The literature shows strong correlation, both statistically and economically, between variables in these areas. Although the issues of causality and the possible existence of underlying factors explaining these observations have not been resolved, LLSV's contributions challenge academics and policymakers alike.

We defined corporate governance as the mechanisms translating signals from product and input markets into corporate behavior. The pressure generated by external investors is just one of these mechanisms. Others include monitoring by employees, suppliers, competitors, and within corporate networks; the government also influence the transmission of signals either directly or through the framework it provides for the corporation. The fact that all these stakeholders do influence decisions in firms has strong normative implications for the role of law in general and investor protection in particular. The various pressures may push the corporation away from efficiency and profit-maximization, in which case strengthened investor protection may be a welcome countervailing force. But the different mechanisms can also substitute for weaknesses in, or complement, monitoring by external investors.

The law can affect these tradeoffs and the accompanying costs and benefits. But these costs and benefits are multi-dimensional, and the law in general, and corporate law in particular, must be careful not to focus excessively on outside investors in their evaluation. Any statement about corporate governance and possible intervention through the legal system must, therefore, be preceded by careful analysis of the specific institutions of the country concerned. The optimal governance arrangements reflect delicate tradeoffs between the benefits and costs of concentrated holdings, employee participation, management structures, corporate networks, and other institutional features of the economy. For example, concentration of ownership improves incentives to monitor management and align incentives of owner/managers with those of the rest of shareholders. The costs come from the agency problems between concentrated owners and minority owners, and the reduced liquidity of shares. Liquidity can be improved by issuing shares with different voting power. But then 
improved liquidity comes at the cost of separation of ownership and control, and the resulting worsening of the agency problem.

Table 3 brings together our (perhaps oversimplified) characterizations of the predominant governance problems in different types of firms.

\section{TABLE 3: THE CORPORATE GOVERNANCE PROBLEM DEFINED - A SIMPLE CLASSIFICATION}

\section{Widely Held Firm}

Strong Managers, Weak Owners

\section{Closely Held Firm}

Strong Blockholders, Weak Minorities

\section{Family Firm}

Strong Managers, No Outsiders

\author{
Transition Firm \\ Omnipotent Managers, \\ Little Resistance
}

\author{
Development Firm \\ Strong Managers, \\ Related Investors
}

We argue that the lessons of LLSV apply primarily to systems where widely held firms dominate and to some extent in transition economies, that is, where the predominant conflict is between managers and external investors. Whether the protection of external investors in Anglo-Saxon systems is too strong, or too weak, is hard to say in general, and there is likely to be important variation across countries with such systems. In many transition economies, in particular those of the former Soviet Union (excluding the Baltic countries), external investors appear excessively weak and the law should aim to strengthen them. For improved investor protection to have an effect on restructuring, however, budget constraints must be hardened, the courts must be more active in settling business disputes, and governments must maintain or create broad political support for economic reforms, at the same time making sure that product and factor markets work sufficiently to provide meaningful signals to firms.

The conceptual framework underpinning LLSV is less well-suited to the analysis of corporate governance in countries with mostly closely held firms, even though most of the measures of investor protection also apply to conflicts between controlling owner/managers and minority investors. As for whether the protection provided is excessive or insufficient, the evidence is inconclusive. LLSV find significant differences between countries with civil law systems, for example, between France and the Netherlands; in fact, the variation among this group of countries may be at least as interesting as the difference between common law and civil law countries. The literature suggests that certain countries in Continental Europe protect minority investors too weakly. Here, Italy is the most frequently given example; in other countries, such as Sweden and Belgium, the verdict seems less clear. There is, however, a general perception that investor protection is weak in many countries. The pressure to reform corporate governance is particularly strong from US-based institutions desiring to diversify their portfolios internationally. Yet, as we have argued in Section 3, economic theory does not 
provide unambiguous guidance in this respect. Therefore, policy recommendations must be preceded by careful investigations of the web of relations governing corporate decision making.

It is less clear that investor protection is a first order problem in most developing countries. Family ownership is the predominant form of control in most countries, often exercised through business groups, and in many countries families have become closely intertwined with government, leading to various forms of crony capitalism. Although this problem is not primarily one of corporate governance, in general, the availability of good investment projects, the strengthening of human capital, the accumulation of physical capital in the country, and government accountability will be among the most important problems for economic policy in most developing countries. The policy mix for reforming corporate governance will then very much depend on the roles played by markets and different stakeholders in different countries. Clearly, better protected investors and functioning financial markets will be part of the solution. In some countries, for instance South Korea, such policies seem to be possible and important, whereas in others their urgency is less clear. In all countries, however, the problem is likely to be one of enforcement rather than of changes in the law.

In the optimistic interpretation of LLSV these reforms of corporate law and investor protection can be achieved by changing the legal text and improving enforcement. A deeper and more pessimistic interpretation of their findings is that legal origin determines investor protection and that changes of this protection require changes in the basic legal system, a very complex task indeed. A similar, but conceptually different interpretation is that some other more fundamental variables explain the observed correlation between legal origin, corporate law, and investor protection. If these variables involve the role of the state or deeply ingrained relationships between different stakeholders in society, reforms are even harder to undertake and will certainly necessitate changes in the society beyond those suggested by the framework of LLSV.

\section{Policy Implications}

The LLSV papers have stimulated an important debate in policy circles, but their policy implications are not as immediate as a superficial reading would suggest, in particular not for developing and transition countries. Despite the constraints and caveats that we have outlined in the preceding sections, we are convinced that there is scope for economic policy on corporate governance. And indeed, it has become very popular to adopt corporate governance guidelines. Many OECD countries have such documents, and OECD itself is about to issue its own set of principles (most guidelines are available from the Web Page of the European Corporate Governance Network at http://www.ecgn.ulb.ac.be). The current draft of the OECD guidelines is an interesting document. Although its focus is still on minority shareholders and the rare species of the widely held corporation, it shows a clear evolution in thinking, in particular as compared to earlier versions and other documents produced by the organization. The preamble recognizes the contextual nature of corporate governance and its dependence on 
the legal, regulatory, and institutional environment. Moreover, the guidelines acknowledge the need to consider stakeholders other than minority shareholders; one of the five basic principles deals with this issue.

The problem with the OECD guidelines, in particular when applied to developing and transition economies, is that they cover a broad range of rules and principles without specifying clear priorities among them. Given that the guidelines assume many of the institutions that are lacking in these countries they also do not provide priorities across policy areas. Furthermore, even the watered-down language of these prescriptions is often too ambitious for policymakers. Nevertheless, we believe the OECD guidelines provide a useful start. To close the paper, we indicate, therefore, in the following paragraphs how we view the priorities for developing and transition countries.

- Any international guidelines must recognize the international differences in governance systems. Generalizations are often more harmful than helpful. Ownership and control structures differ tremendously and so do the basic mechanisms for correcting governance failures and the roles of different governance institutions. General principles do exist, however, and should be articulated, in particular when they are unlikely to be so locally. At least, they force domestic actors to make explicit their own preferences.

- The general accounting rules and transparency requirements of the OECD guidelines should be a benchmark. Transparency concerning ownership and control arrangements is desirable, in particular in improving the liquidity of shares and attracting foreign investors. It is hard to see how there can be any significant social costs to such disclosure, and the benefits seem substantial. The puzzle is to explain why companies in need of external finance have not implemented these guidelines on their own initiative. Doing so would presumably lower their cost of capital. The failure of the Transparency Directive of the European Union also shows that resistance or inertia is considerable. Either companies do not need (or want) outside funds or there are substantial private costs to disclosure. One hypothesis is that insiders to these arrangements are concerned that their legitimacy would be undermined.

- Protection of external investors is more important in transition economies than in developing countries. The emphasis in LLSV is most appropriate in transition economies where many managers have entrenched themselves in formerly state-owned companies. However, the necessary pressure for change will not come from small shareholders or takeover threats in anonymous equity markets, but rather must come from strategic investors with large stakes, or even from the labor force, political authorities, or others.

- The development effect from any program that focuses solely on the plight of small shareholders is likely to be very small. It is not clear that access to external funds is a binding constraint for most firms in developing countries. Even where it is, small, anonymous shareholdings will in most cases not be the dominant source of capital. Protection of strategic equity investors can be important, but most finance is likely to come through family ties or, possibly, peer group arrangements. The conclusion is equally 
valid for transition economies. This is not to say that small shareholder protection should not be part of corporate governance, it just should not be the main focus.

- Protection of creditors is more important than that of shareholders in developing and transition economies. Debt is the dominant source of external finance in developed market economies. In relative terms, equity currently is more important in developing countries. But equity is typically raised not in public markets but through family ties or personal relationships. In the short term, substantial increases in external finance are likely to take the form of debt, probably from banks. Recent studies show a strong link between creditor protection and the development of the banking sector. In most transition economies companies have not been successful in raising external finance, but the need is great. Strategic shareholders are important to achieve restructuring, but most external capital in these countries, too, is likely to come as debt.

- The short- and medium-term emphasis on investor protection should not be on creating liquid markets for shares and corporate bonds. The reason is not that liquid markets and liquidity, as is sometimes argued, are undesirable. Liquid markets generate information and facilitate control transactions in many developed market economies. In developing economies, liquidity is most important when families have to sell out, but this does not seem to be a first-order problem in the short and medium term. In some transition economies liquid equity markets could play a role in helping strategic investors build positions, but it is not clear that insiders will issue shares to let this happen.

- In the long term, liquid securities markets can be important for attracting foreign portfolio investment. These markets are hard to create, take time to develop and are difficult to sustain. In most countries they do not have an important role as a source of finance. The recent problems in Asia and Russia have also demonstrated how volatile these markets are, but the vulnerability of individual countries seems to be closely related to how well protected external investors are. This may be the type of investment where investor protection matters most. Foreign portfolio investment has important benefits in relieving domestic capital constraints, and the lure of such investment can be important in the implementation of governance reform.

- Reforms focusing on enforcement are more important, and more difficult, than are changes to the letter of the law. This obvious point needs to be made. Unfortunately, we have not had much to say about how to strengthen enforcement and promote the rule of law. Self-enforcement is necessary, given the weakness of the legal institutions, but as the experience from Russian corporate law reform demonstrates it is not sufficient.

- Reforms must recognize the complementarity of different parts of the law and political institutions. In countries with strong law enforcement, legal protection and obligations of economic actors must be different from those in ones with weak enforcement. The efficiency of legal procedures, such as the scope of criminal or civil law in business court cases or the use of circumstantial evidence in court, will depend on the overall legal framework and the political structure of the country. 
- In many contexts the most immediate concern is to protect stakeholders other than shareholders. In many transition countries, Russia in particular, the main governance problem is entrenched managers' outright theft from, or at least failure to pay, the government and employees. Ruthless managers also exploit suppliers and customers locked into inherited technological relationships. Weak labor laws in many developing countries discourage firm-specific investment by employees and could also undermine general skill formation. Obviously, a stakeholder approach can allow managers and individual stakeholders to exploit blurred corporate objectives and paralyze decisionmaking. But corporate governance reform must strike a balance between financial and non-financial stakeholders and recognize the needs, and in particular the potential value added, of stakeholders other than shareholders.

- Implementation and enforcement of fundamental corporate governance reform will in many cases require external conditionality. Governments in developing and transition countries are generally weak. This weakness has many sources, but one important reason, in particular in transition economies, is the political deadlock over central parts of reform. These deadlocks arise out of the distribution effects of reforms. External conditionality can relieve these political constraints. The role of the European Union as an outside anchor to the reform process has been crucial to institutional reform in Central and Eastern Europe. Unfortunately, EU membership has not been in the cards for most of the former Soviet Union (the Baltic countries excluded). Conditionality from the international financial institutions could also go some way and should be systematically used, but it can never have the same leverage effect. For corporate governance reform, explicit or implicit conditions formulated by foreign investors are also important, but this pressure is likely to be less consistent and less coordinated. Here OECD and other guidelines may be useful.

- Effective corporate governance reform will often require a combination of threats and co-optation of the main actors. Given the weakness of governments and the absence of credible outside anchors in most developing and transition economies, fundamental reform will not be undertaken against the will of the main actors. Pivotal groups will somehow have to be co-opted. In other cases, threats may be necessary. In the extreme case of Russia, re-nationalization of strategic assets followed by renewed privatization may be the only way to break resistance. Yet, this measure has obvious reputation consequences and the government may not be strong enough to act on such a threat. 


\section{References}

Aoki, Masahiko, 1998, «A Theoretical Foundation for Comparative Corporate Governance,» manuscript, Stanford University.

Barca, Fabrizio and Marco Becht (eds.), 1999, Ownership and Control: A European Perspective, manuscript, Free University of Brussels.

Berglöf, Erik, 1997, «Reforming Corporate Governance: Redirecting the European Agenda,» Economic Policy, 93-123.

Berglöf, Erik, and Gérard Roland, 1998, «Soft Budget Constraints and Banking in Transition,» Journal of Comparative Economics, 18-40.

Berglöf, Erik, Gérard Roland and Ernst-Ludwig von Thadden, 1999, «The Hypothetical Creditors’ Bargain,» manuscript, SITE, Stockholm School of Economics.

Bhagwati, Jagdish, 1993, India in Transition: Freeing the Economy, Oxford: Clarendon Press.

Black, Bernard and Reinier Kraakman, 1996, «Self-Enforcing Model of Corporate Law», Harvard Law Review 109, 1911-1981.

Black, Bernard, Reinier Kraakman, and Anna Tarassova, 1999, «Russian Privatization and Corporate Governance: What Went Wrong?», manuscript, Stanford University.

Blanchard, Olivier and Michael Kremer, 1997, «Disorganization», Quarterly Journal of Economics, 1091-1126.

Bolton, Patrick and Ernst-Ludwig von Thadden, 1998, «Block, Liquidity and Corporate Governance,» Journal of Finance, 1-25.

Brown, Annette and David Brown, 1998, «Does Market Structure Matter,» SITE Working Paper, Stockholm School of Economics.

Burkart, Mike, Denis Gromb, and Fausto Panunzi, 1997, «Large Shareholders, Monitoring and the Value of the Firm,» Quarterly Journal of Economics, 693-728.

Claessen, Stijn, Simeon Djankov and Larry H. P. Long, 1998, «Who Controls East Asian Corporations?,» manuscript, The World Bank.

Dewatripont, Mathias and Gérard Roland, 1997, «Transition as Large-Scale Institutional Change» in D. Kreps (ed.), Cambridge University Press

Earle, John and Saul Estrin, 1998, «Privatization, Competition, and Budget Constraints:

Disciplining Enterprises in Russia,» SITE Working Paper, Stockholm School of Economics. 
EBRD Transition Report, 1996, European Bank of Reconstruction and Development.

EBRD Transition Report, 1998, European Bank of Reconstruction and Development.

ECGN, 1998, «Corporate Governance and Disclosure in a Transatlantic Perspective,» draft report, Centre for Economic Policy Research and European Corporate Governance Network, Brussels.

Fisman, Raymond, 1998, «The Incentives for Rent-Seeking: Estimating the Value of Political Connections,» manuscript, Harvard University.

Granovetter, Mark (1994), Business Groups, in N. Smelser and R. Swedberg (eds.), Handbook of Economic Sociology, Princeton: Princeton University Press.

Grossman, Sanford and Oliver Hart, 1986, «The Costs and Benefits of Ownership: A Theory of Vertical and Lateral Integration,» Journal of Political Economy; 691-719.

Gugler, Klaus, 1998, «Corporate Governance and Economic Performance,» manuscript, University of Vienna.

Hart, Oliver and John Moore, 1990, «Property Rights and the Nature of the Firm,» Journal of Political Economy, 1119-58

Hay, Jonathan R; Shleifer, Andrei, 1998, «Private Enforcement of Public Laws: A Theory of Legal Reform», American Economic Review 88, 398-403.

Hellwig, Martin, 1998, «On the Economics and Politics of Corporate Finance and Corporate Control», manuscript, Universität Mannheim.

Jensen, Michael, 1993, «The Modern Industrial Revolution, Exit and the Failure of Internal Control Systems», Journal of Finance, 831-80.

Johnson, Simon, Peter Boone, Alisdair Breach and Eric Friedman, 1998, «Corporate Governance and the Asian Financial Crisis», manuscript, MIT.

Khanna, Tarun and Krishna Palepu, February 1999, «Emerging Market Business Groups, Foreign Investors, and Corporate Governance,» manuscript, Harvard Business School. Also: NBER Working Paper Series, Working Paper 6955.

Khanna, Tarun and Jan W. Rivkin, 1999, «Estimating the Performance Effects of Networks in Emerging Markets,» manuscript, Harvard University.

King, Robert and Ross Levine, 1993, «Finance and Growth: Schumpeter Might be Right,» Quarterly Journal of Economics, 108, 717-38. 
LaPorta, Rafael, Florencio Lopez-de-Silanes, Andrei Shleifer and Robert Vishny, 1997, «Legal Determinants of External Finance,» Journal of Finance 52: 1131-1150.

LaPorta, Rafael, Florencio Lopez-de-Silanes, Andrei Shleifer and Robert Vishny, 1998, «Law and Finance», Journal of Political Economy 106, 1113-1155.

LaPorta, Rafael, Florencio Lopez-de-Silanes, and Andrei Shleifer, 1999a, «Corporate Ownership Around the World,» Journal of Finance 54: 471-517.

LaPorta, Rafael, Florencio Lopez-de-Silanes, and Andrei Shleifer, 1999b, «Agency Problems and Dividend Policies Around the World,» Journal of Finance, (forthcoming).

Levine, Ross, Norman Loayza and Torsten Beck, 1998, «Financial Intermediation and Growth: Causality and Causes,» manuscript, World Bank.

Linnarud, Christina, 1998, «Corporate Governance and Shareholder Rights in the Russian Law», manuscript.

Lombardo, Davide and Marco Pagano, 1999, «Legal Determinants of the Cost of Equity Capital,» Presented at the 1999 Journal of Financial Intermediation Symposium, Cornell University, Ithaca, New York.

Mayer, Colin, 1990, «Financial Systems, Corporate Finance, and Economic Development,» in R.G. Hubbard (ed.) Asymmetric information, corporate finance, and investment Chicago and London: University of Chicago Press, 1990, 307-32.

Nickell, Stephen,1996, «Competition and Corporate Performance,» Journal of Political Economy, 724-46.

Nickell, Stephen, Daphne Nicolitsas and Neil Dryden,1997, «What Makes Firms Perform Well?,» European Economic Review, 783-96.

OECD, 1999, Draft OECD Principles of Corporate Governance.

Rajan, Raghuram, Henri Servaes, and Luigi Zingales, 1998, «The Cost of Diversity :

Diversification Discount and Inefficient Investment», manuscript, GSB Chicago.

Rajan, Raghuram and Luigi Zingales, 1998, «Finance Dependence and Growth,» American Economic Review 88, 559-29.

Rajan, Raghuram and Luigi Zingales, 1999, «The Tyranny of the Inefficient: An Inquiry into the Adverse Consequences of Power Struggles,» manuscript, GSB Chicago. 
Roe, Mark, 1994, Strong Managers, Weak Owners: The Political Roots of American Corporate Finance, Princeton: Princeton University Press.

Roe, Mark, 1999, «Political Preconditions to Separating Ownership from Control: The Incompatibility of the American Public Corporation with Social Democracy,» manuscript, Columbia Law School.

Samuelson, Paul, 1957, «Wages and Interest : A Modern Dissection of Marxian Economic Models », American Economic Review 47, 884-912.

Schaffer, Mark, 1998, «Do Firms in Transition Economies Have Soft Budget Constraints? A Reconsideration of Concepts and Evidence», Journal of Comparative Economics 26, 80-103.

Shleifer, Andrei, and Lawrence Summers, 1988, «Breach of Trust in Hostile Takeovers», in A.J. Auerbach (ed.), Corporate Takeovers: Causes and Consequences, Chicago and London: University of Chicago Press, 33-56.

Shleifer, Andrei and Robert Vishny, 1997, «A Survey of Corporate Governance,» Journal of Finance 52, 737-783.

Stein, Jeremy, 1988, «Takeover Threats and Managerial Myopia », Journal of Political Economy 96, 61-80.

von Thadden, Ernst-Ludwig, 1995, «Long Term Contracts, Short Term Investment and Monitoring». Review of Economic Studies, 557-75.

Tirole, Jean, 1998, «Corporate Governance,» CEPR Discussion Paper Series.

Zingales, Luigi, 1995, «What Determines the Value of Corporate Votes?,» Quarterly Journal of Economics 110, 1047-1073.

Zingales, Luigi, 1999, «Legal Systems and Financial Development,» manuscript, GSB Chicago. 